Vol. 20(2011): 235-244.

\title{
Meat bone meal as fertiliser for barley and oat
}

\author{
Lin Chen ${ }^{1}$, Jukka Kivelä ${ }^{1 *}$, Juha Helenius ${ }^{1}$ and Arjo Kangas ${ }^{2}$ \\ ${ }^{1}$ Department of Agricultural Sciences, Fin-00014 University of Helsinki \\ ${ }^{2}$ MTT Agrifood Research Finland, Alapääntie 104, 61400 Ylistaro, Finland \\ *e-mail:jukka.kivela@helsinki.fi
}

\begin{abstract}
The traditional production of mineral $\mathrm{N}$ and $\mathrm{P}$ fertilisers is unsustainable due its reliance on fossil fuels in the case of $\mathrm{N}$, and on limited mineral resource stocks in the case of $\mathrm{P}$. The use of alternative or complementary fertilisers that originate from organic waste materials is gaining interest. Organic farms, especially arable organic farms without livestock, need usable sources of plant nutrients. Meat bone meal (MBM), a potential organic fertiliser for agricultural crops, contains considerable amounts of nutrients (on average $8 \% \mathrm{~N}, 5 \% \mathrm{P}, 1 \% \mathrm{~K}$ and $10 \% \mathrm{Ca}$ ). In EU countries, Commission regulation (EC) No 181/2006 authorised the use of MBM as an organic fertiliser. In this study, MBM was compared to conventional mineral NPK fertiliser. Two randomised complete block split-plot field experiments were conducted: one with spring barley (Hordeum vulgare) in two years; and another with oat (Avena sativa) for three years, including a fourth year of testing for residual effect. Compared to mineral fertiliser ( $20 \% \mathrm{~N}, 3 \% \mathrm{P}$ and $9 \% \mathrm{~K}), \mathrm{MBM}$ was applied at three $\mathrm{N}$ levels: 60,90 and $120 \mathrm{~kg} \mathrm{~N} \mathrm{ha}^{-1}$. The grain yield of both cereal species supported by MBM, did not differ from the yield obtained with the mineral fertiliser at any $\mathrm{N}$ level. At $120 \mathrm{~kg} \mathrm{~N} \mathrm{ha}^{-1}$, the grain yield level with either type was ca. $4500 \mathrm{~kg} \mathrm{ha}^{-1}$ of barley and $5000 \mathrm{~kg} \mathrm{ha}^{-1}$ of oat, representing fair averages for Finnish conditions. Moreover, MBM and mineral fertilisation showed no differences in quality in terms of 1000-grain weight, test-weight, protein content and protein yield. Since MBM has a low $\mathrm{N} / \mathrm{P}$ ratio, $\mathrm{P}$ was applied in surplus to attain comparable $\mathrm{N}$ levels. Therefore MBM fertilisation should be fitted for crop rotation and for meeting environmental requirements.
\end{abstract}

Key-words: meat bone meal, nitrogen, phosphorus, organic fertiliser 


\section{AGRICULTURAL AND FOOD SCIENCE}

Chen, L. et al. Meat bone meal as fertiliser for barley and oat

\section{Introduction}

As a product of the rendering industry, $\mathrm{MBM}$ contains about $8 \% \mathrm{~N}, 5 \% \mathrm{P}, 1 \% \mathrm{~K}$ and $10 \% \mathrm{Ca}$, varying according to the rendering process and to the origin of the offal. Before MBM was suspected as the cause of bovine spongiform encephalopathy (BSE) when fed to ruminants, it was commonly used to feed animals (Brewer 1999). The use of animal meal in the food and feed industry was banned in 2000, and its use as fertiliser material is currently strictly regulated in the European Union (EU) (Werner 2003). Since 2006, however, Commission regulation (EC) No 181/2006 has permitted the use MBM as fertiliser for arable crops in the EU.

Following the overall idea of industrial ecology (Graedel 1996, Frosch and Gallopoulos 1989), the recycling of nutrients in MBM should improve the eco-efficiency of natural resource use in the food system. The annual production of MBM in the $\mathrm{EU}$, for example, was about three million tonnes in 2001 (Werner 2003). The total amount of $\mathrm{N}$ and $P$ from animal meals in 15 EU countries could be estimated at 120 million $\mathrm{kg} \mathrm{N}$ and 155 million $\mathrm{kg}$ $\mathrm{P}$, or about 360 million $\mathrm{kg} \mathrm{P}_{2} \mathrm{O}_{5}$ (Werner 2003). In Finland, at least 200 million $\mathrm{kg}$ (fresh weight, in ca. $35 \%$ moisture content) of animal by-products are generated annually (Salminen 2002), of which about 15 million $\mathrm{kg}$ are classified as high-risk material and must be incinerated. The sales for fertiliser nutrients were about 154 million $\mathrm{kg}$ of $\mathrm{N}$ and 12 million $\mathrm{kg}$ of $\mathrm{P}$ in Finland in 2009. If all but the high-risk fraction of Finnish animal by-products were recycled as fertiliser, the amount of nutrients would equal at least $6 \%$ of $\mathrm{N}$ and $50 \%$ of $\mathrm{P}$ in the industrial chemical fertilisers used on Finnish agricultural lands.

As a fertiliser, MBM has recently been tested for cereals. Jeng et al. $(2004,2006)$ found MBM to be an effective organic fertiliser for spring wheat and barley. Salomonsson et al. (1994, 1995) studied the impact of MBM fertiliser on the grain protein content in spring and winter wheat and found $\mathrm{N}$ availability in MBM to be similar to that in urea. Additionally, MBM has been found to provide sufficient $\mathrm{N}$ for good baking performance of organi- cally grown wheat (Fredriksson et al. 1997). The concentration of heavy metals, the endogenous infection of moulds, and mycotoxins showed no consistent differences in wheat fertilised with MBM or with urea (Salomonsson et al. 1995). Using MBM as a fertiliser could also reduce the incidence of potato scab (Verticillium dahliae) and curb populations of parasitic nematodes (Lazarovits et al. 1999).

The availability of $\mathrm{P}$ in MBM has also been studied. $\mathrm{P}$ is mostly present in MBM as apatite in the bone fraction whereas it exists in organic form in the meat fraction (Jeng et al. 2006). $\mathrm{pH}$ is an important factor influencing $\mathrm{P}$ release from bone meal. Ylivainio et al. (2007) found that $90 \%$ of $\mathrm{P}$ in MBM was soluble only in $1 \mathrm{M} \mathrm{HCl}$. P in MBM has a residual effect: $\mathrm{P}$ applied in soil will remain for at least three to five years in acid soils and even longer if the $\mathrm{pH}$ is over 6.5. In barley and canola seed production, bone meal proved to be a more effective P fertiliser than rock phosphate (Bekele and Höfner 1993).

The aim of this study was to analyse the effect of MBM as an organic fertiliser on crop yield and quality, and to compare this with conventional mineral fertiliser. In particular, the aim was to compare the effects over a range of $\mathrm{N}$ fertilisation levels, in order to obtain applicable results for recommendations to farmers. Spring cereals barley and oat were chosen as test crops because of their importance in Finland.

\section{Materials and methods}

\section{Study area and soil analysis}

The experiments were carried out during 2000-2003 at the Ylistaro research station $\left(62^{\circ} 56^{\prime} 25^{\prime \prime} \mathrm{N}\right.$, $22^{\circ} 31^{\prime} 0^{\prime \prime}$ E) of MTT Agrifood Research Finland. Ylistaro is located in the boreal zone in the province of Western Finland. Agriculture in the region is dominated by production of spring cereals such as barley, especially for feed, oat, wheat and spring canola. 
Vol. 20(2011): 235-244.

The weather conditions were typical of the region. May 2001 stands out as cooler and rainier than the month of May in the other years of experimentation (Table 1). The soil had a texture of silty clay loam. According to the WRB system (FAO 2006), the experimental soil was tentatively classified as Endogleyic Cambisols (Humid, Dystric, Siltic) (see also Yli-Halla et al. 2000). The soil was classified in the category of low organic matter content, with a class range of 3-6\% organic matter (Table 2). Soil P, K, Ca, and Mg were extracted by acid ammonium acetate, $\mathrm{pH} 4.65$, ratio $1: 10 \mathrm{v} / \mathrm{v}$, $1 \mathrm{~h}$ (Vuorinen and Mäkitie 1955).

\section{Material used in the experiment}

The spring barley (Hordeum vulgare L.) cultivar used in the experiment was Thule, a six-row barley. The spring sown oat (Avena sativa L.) cultivar in 2000 and 2001 was Veli, and in 2002 and 2003 Belinda. Seed dressing fungisides were not applied. Pellon Y3® 20-3-9 (PY3) from Kemira GrowHow, a granular mineral fertiliser with $20.0 \% \mathrm{~N}$ (about $11.0 \%$ ammonium, $9.0 \%$ nitrate), $3.0 \% \mathrm{P}$ and $9.0 \%$ $\mathrm{K}$, served as the mineral comparison. Other nutrient content in PY3 includes $0.5 \%$ magnesium, 3.0\% sulfur, $0.02 \%$ boron and $0.0015 \%$ selenium. Honkajoki Oy provided MBM 7-5-1 for the experiment as well as the data on its content (Table 3).

Table 1. Temperature and rainfall in the growing seasons from 2000 to 2002, and in the 1960-91 reference period at Ylistaro.

\begin{tabular}{|c|c|c|c|c|c|c|c|c|c|c|}
\hline \multirow[b]{2}{*}{ Month } & \multicolumn{5}{|c|}{ Mean temperature $\left({ }^{\circ} \mathrm{C}\right)$} & \multicolumn{5}{|c|}{ Total Rainfall (mm) } \\
\hline & 2000 & 2001 & 2002 & 2003 & 1960-91 & 2000 & 2001 & 2002 & 2003 & $1960-91$ \\
\hline May & 10.3 & 7.6 & 11.3 & 9.7 & 8.8 & 36.9 & 89.2 & 44.4 & 69.5 & 38 \\
\hline June & 13.9 & 14.2 & 15.8 & 13.1 & 14.0 & 38.5 & 63.0 & 64.2 & 68.2 & 42 \\
\hline July & 16.1 & 17.6 & 18.1 & 19.5 & 15.5 & 75.2 & 61.4 & 82.3 & 72.3 & 68 \\
\hline Aug & 13.9 & 14.5 & 17.7 & 14.3 & 13.6 & 77.6 & 79.4 & 56.6 & 31.2 & 70 \\
\hline Mean & 13.6 & 13.5 & 13.5 & 14.2 & 13.0 & 228.2 & 293.0 & 247.5 & 241.2 & 218 \\
\hline
\end{tabular}

Table 2. Soil pH and nutrient contents in the experimental fields of barley and oat in 2000, before the experiments.

\begin{tabular}{lcccc}
\hline & Barley & Conditions & Oat & Conditions \\
\hline $\mathrm{pH}$ & 5.8 & tolerable & 5.4 & rather low \\
$\mathrm{Ca}, \mathrm{mg} \mathrm{l}^{-1}$ & 726 & rather low & 728 & rather low \\
$\mathrm{P}, \mathrm{mg} \mathrm{l}^{-1}$ & 7.0 & tolerable & 5.5 & tolerable \\
$\mathrm{K}, \mathrm{mg} \mathrm{l}^{-1}$ & 131 & acceptable & 113 & tolerable \\
${\mathrm{Mg}, \mathrm{mg} \mathrm{l}^{-1}}^{173}$ & acceptable & 144 & acceptable \\
\hline
\end{tabular}

${ }^{1}$ The growth condition interpreted according to the Finnish standard system of soil fertility assessment (for details, see for example Peltovuori 1999). 


\section{AGRICULTURAL AND FOOD SCIENCE}

Chen, L. et al. Meat bone meal as fertiliser for barley and oat

Table 3. The macronutrient (\%), micronutrient $\left(\mathrm{mg} \mathrm{kg}^{-1}\right)$ and heavy metal $\left(\mathrm{mg} \mathrm{kg}^{-1}\right)$ content of MBM. The data are from an analysis of the rendering plant (Honkajoki Oy in Finland) from which the MBM used in the experiment originated (ws = water soluble).

\begin{tabular}{lllcll}
\hline Macronutrients & \multicolumn{2}{c}{ Micronutrients } & \multicolumn{2}{c}{ Heavy metals } \\
\hline $\mathrm{N}$ & 7.0 & $\mathrm{~B}$ & 25 & $\mathrm{~Pb}$ & 0.50 \\
$\mathrm{~N}$ ws & 2.5 & $\mathrm{Co}$ & 0.15 & $\mathrm{Cd}$ & 0.1 \\
$\mathrm{P}$ & 5 & $\mathrm{Cu}$ & 3.9 & $\mathrm{Hg}$ & 0.01 \\
$\mathrm{P}$ ws & 0.15 & $\mathrm{Fe}$ & 58 & $\mathrm{Ni}$ & 0.55 \\
$\mathrm{~K}$ & 1 & $\mathrm{Mn}$ & 4 & & \\
$\mathrm{Ca}$ & 12.0 & $\mathrm{Zn}$ & 55 & & \\
$\mathrm{Mg}$ & 0.8 & $\mathrm{Se}$ & 0.19 & & \\
$\mathrm{~S}$ & 0.5 & & & & \\
$\mathrm{Na}$ & 0.5 & & & & \\
\hline
\end{tabular}

\section{Experimental design}

The two experiments were both factorial randomised complete block split-plot designs with four replicates. The sowing and harvesting dates of barley were 19 May, 17-19 August 2000; and 22 May, 16-20 August 2001. The dates for oat were 19 May, 27-28 August 2000, 22 May, 20-24 August 2001, and 15 May, 15 August 2002. These dates were typical to farming in the area. To test for a residual effect on the following year's crop, the experiment with oat was continued into 2003. In this final year, all the plots were sown 22 May with cv. Belinda without fertiliser. The experimental plots were physically maintained in the same places over the years. The main plot size was $2.2 \mathrm{~m} \times 10$ $\mathrm{m}$. The blocks were placed $3 \mathrm{~m}$ apart.

The main plot factor was fertilisation rate at three levels, adjusted for $\mathrm{N}$ at steps 60, 90, and 120 $\mathrm{kg} \mathrm{ha}^{-1}$ (Table 4). At each $\mathrm{N}$ step, levels at which $\mathrm{P}, \mathrm{K}$, and the other nutrients were applied also increased at the same rate as $\mathrm{N}$. The sub-plot factor was fertiliser type. In addition to treatments derived from factorial combinations of fertiliser application rate $\mathrm{x}$ fertiliser type, an additional control plot (no fertilisation) was randomised for each block.

\section{Crop management}

The crops were rain-fed. Based on monitoring for need of pest control, control measures were not needed. Weeds were controlled by spraying with standard tribenuron-methyl herbicide Express Classic $®$ and fluroxypyr herbicide Starane $® 0.41 \mathrm{ha}^{-1}$. The previous crop in the barley experiment was rye; in the oat experiment, the crops were winter rye and wheat.

\section{Measurements}

Barley and oat grain yields $\left(\mathrm{kg} \mathrm{ha}^{-1}\right)$ were harvested and reported at $15 \%$ moisture. Four parameters of grain quality, namely 1000-grain weight (TGW, g), test weight $\left(\mathrm{kg} \mathrm{hl}^{-1}\right)$, protein content $(\%)$ and pro-

Table 4. Amount of fertiliser and N, P, and $\mathrm{K}$ applied in the experiments $\left(\mathrm{kg} \mathrm{ha}^{-1}\right)$.

\begin{tabular}{llrrrrrrrr}
\hline & \multicolumn{3}{c}{$\mathrm{N} \mathrm{60}$} & \multicolumn{3}{c}{$\mathrm{N} \mathrm{90}$} & \multicolumn{3}{c}{ N 120 } \\
\hline Fertiliser type & Fertiliser & $\mathrm{P}$ & $\mathrm{K}$ & Fertiliser & $\mathrm{P}$ & $\mathrm{K}$ & Fertiliser & $\mathrm{P}$ & $\mathrm{K}$ \\
PY3 & 300 & 9 & 27 & 450 & 14 & 41 & 600 & 18 & 54 \\
MBM & 857 & 43 & 9 & 1285 & 64 & 13 & 1714 & 86 & 17 \\
\hline
\end{tabular}


Vol. 20(2011): 235-244.

tein yield $\left(\mathrm{kg} \mathrm{ha}^{-1}\right)$, were analysed. Protein content was measured with the Kjeldahl method at MTT's laboratory in Jokioinen.

\section{Data analysis}

Analysis of variance (ANOVA) was performed with SPSS $®$ according to the experimental design. The GLM repeated measures procedure was used to test linear response effects in the full factorial split-split plot design. The year was included as the split-split plot level factor (Gomez and Gomez 1984, pp. 153 and 265), as the treatments defined by fertilisation rate $\times$ fertiliser type, and the respective measurements at split-plot level were repeated over two years (in the case of barley) or three years (in the case of oat). When including the control, the MBM and PY3 fertiliser effects were analysed separately, the model being a fully randomised complete blocks ANOVA at the main plots level. Tukey's test was used to compare means at a $5 \%$ risk.

Nitrogen use efficiency (NUE \%) was calculated as the degree of recovery of fertiliser. NUE was measured by the following equation: $\operatorname{NUE}(\%)=(\mathrm{N}$ uptake $\left(\mathrm{kg} \mathrm{ha}^{-1}\right)$ in fertilised plots $-\mathrm{N}$ uptake $\left(\mathrm{kg} \mathrm{ha}^{-}\right.$ $\left.{ }^{1}\right)$ in unfertilised plots) / $\mathrm{N}$ application rate $\left(\mathrm{kg} \mathrm{ha}^{-1}\right)$.

\section{Results \\ Grain yield}

The same barley grain yield (Fig.1) was obtained with MBM as with PY3 (no significant difference). Barley grain yield increased from $3561 \mathrm{~kg} \mathrm{ha}^{-1}$ (SD $=307 \mathrm{~kg} \mathrm{ha}^{-1}, \mathrm{n}=16$ ) at the lowest fertilisation level to $4309 \mathrm{~kg} \mathrm{ha}^{-1}\left(\mathrm{SD}=476 \mathrm{~kg} \mathrm{ha}^{-1}, \mathrm{n}=32\right)$ at the two higher fertilisation levels $(p<0.05)$. Compared to unfertilised control, less yield increase was obtained with fertilisation in the first year than in the second year $(p<0.01)$. In the first year, PY3 significantly increased barley yield by $41 \%$ only at the highest fertilisation level and MBM by $40 \%$ at the two highest levels $(p<0.05)$. In the second year, both PY3 and MBM significantly increased barley yield by $91 \%$ and $84 \%$ respectively $(p<0.000)$ even at the lowest fertilisation level.

As with barley, oat grain yield (Fig. 2) did not differ between the fertiliser types. In the fertilised

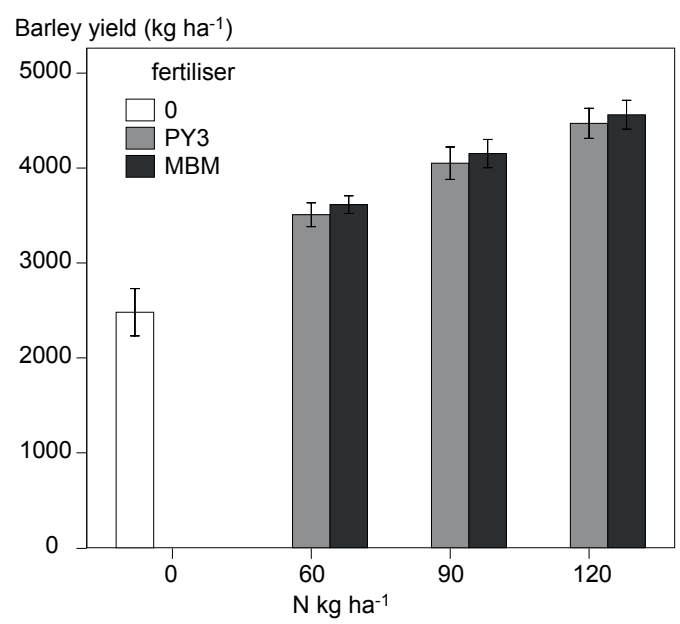

Fig. 1. Barley grain yield in 2000 and 2001. Comparison at three N-levels of the effect of meat bone meal (MBM) with the effect of mineral fertiliser (PY3), and with a control without fertilisers.

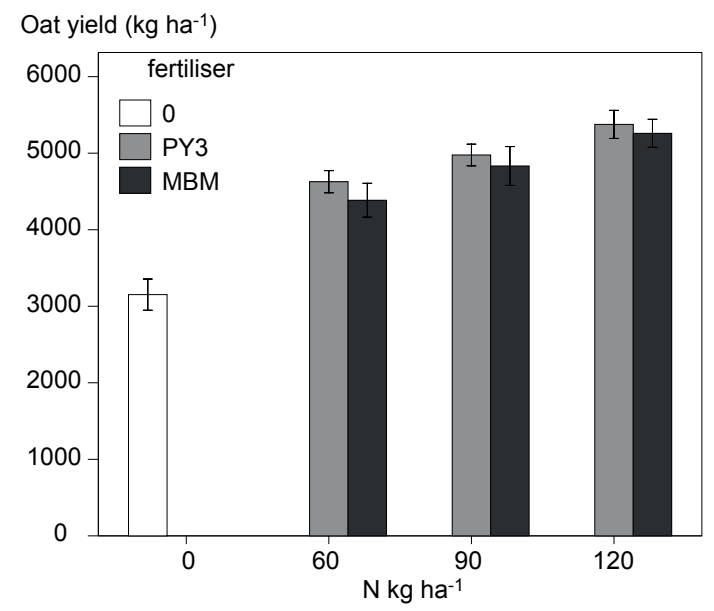

Fig. 2. Oat grain yield in 2000, 2001 and 2002 . Comparison at three N-levels of the effect of meat bone meal (MBM)with the effect of mineral fertiliser (PY3), and with a control without fertilisers. 


\section{AGRICULTURAL AND FOOD SCIENCE}

Chen, L. et al. Meat bone meal as fertiliser for barley and oat

treatments, the average oat yield was $4913 \mathrm{~kg} \mathrm{ha}^{-1}$ ( $\left.\mathrm{SD}=708 \mathrm{~kg} \mathrm{ha}^{-1}, \mathrm{n}=69\right)$, and differences among the fertilisation levels were not significant. Compared to unfertilised control, both fertilisers significantly increased oat yield at the two highest fertilisation levels. In the first year, PY3 increased oat yield even at the lowest application rate $(p<0.01)$.

\section{Residual effect on oat grain yield}

The result showed that MBM had a higher residual fertilisation effect on oat grain yield than PY3 ( $p$ $<0.05$ ). The plots fertilised by MBM in the three previous years produced, on an average, $381 \mathrm{~kg}$ $\mathrm{ha}^{-1}(20 \%)$ more than the plots fertilised by PY3 (Fig. 3). The advantage of MBM over PY3 was consistent over all the three fertilisation levels (no significant interaction).

The residual effect on yield increased with increasing fertilisation level $(p<0.05)$. There was a significant rise in oat grain yield from $1780 \mathrm{~kg}$ $\mathrm{ha}^{-1}\left(\mathrm{SD}=165 \mathrm{~kg} \mathrm{ha}^{-1}, \mathrm{n}=7\right)$ in the plots that had

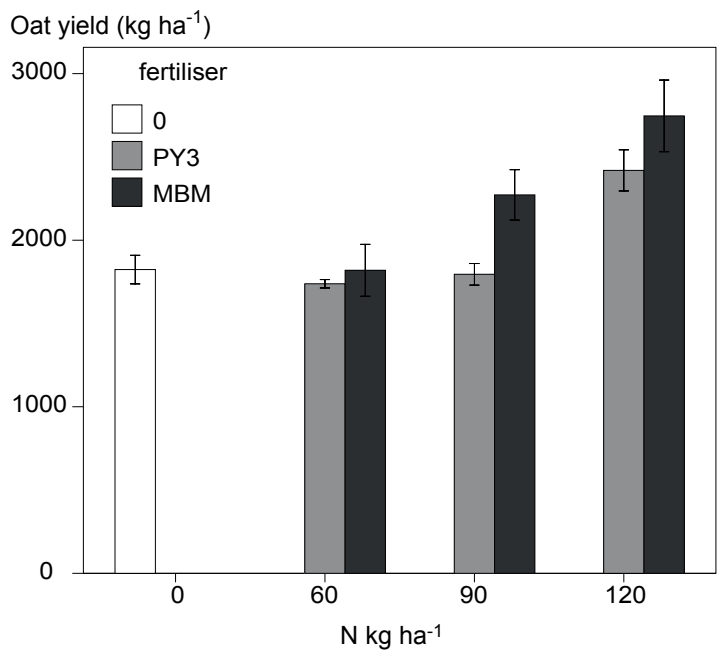

Fig. 3. Oat grain yield in the fourth year (2003), in which fertilisers were not applied, after three previous seasons of fertilisation. Comparison at three $\mathrm{N}$ levels of the residual effect of meat bone meal (MBM) with the residual effect of mineral fertilizer (PY3), and with a control of no fertilization $(0)$ in the three previous years. received the lowest fertilisation level in the three previous years, to $2606 \mathrm{~kg} \mathrm{ha}^{-1}\left(\mathrm{SD}=372 \mathrm{~kg} \mathrm{ha}^{-}\right.$ ${ }^{1}, \mathrm{n}=7$ ) in the plots with a history of the highest fertilisation level (Tukey's test, $p<0.05$ ) (Fig. 3). In comparison to the unfertilised control (Fig. 3), oat grain yield significantly increased only when the fertilisation rate in the previous years had been the highest (Tukey's test, $p<0.05$ ).

\section{0-grain weight (TGW)}

Average TGW of barley (Table 5) was $39.8 \mathrm{~g}$ (SD $=2.3 \mathrm{~g}, \mathrm{n}=54)$. No consistent effect of either fertiliser type or fertilisation level on barley TGW over the two years was found (three-way interaction, $p<0.05)$. In comparison to unfertilised control, in the first year, both PY3 and MBM significantly increased barley TGW only at the highest fertilisation level $(p<0.05)$. In the second year, PY3 at the two highest fertilisation levels and MBM at the lowest fertilisation level significantly increased barley TGW $(p<0.001)$.

Average TGW of oat was $40.2 \mathrm{~g}(\mathrm{SD}=1.9$ $\mathrm{g}, \mathrm{n}=70$ ). Oat TGW did not differ between the two fertiliser types nor between the fertilisation levels and no interaction between the factors was found. In comparison to unfertilised control, applying PY3 increased oat TGW by $4 \%$ at the two highest application levels $(p<0.05)$, but applying MBM did not have a significant effect. No significant residual effect on oat TGW was found.

\section{Test weight}

Barley test weight (Table 5) did not depend on fertiliser type. A significant $(p<0.05)$ increase in barley test weight from $64.4 \mathrm{~kg} \mathrm{~h}^{-1}(\mathrm{SD}=2.8$ $\mathrm{kg} \mathrm{hl}^{-1}, \mathrm{n}=16$ ) at the lowest fertilisation level to an average $65.5 \mathrm{~kg} \mathrm{hl}^{-1}\left(\mathrm{SD}=2.7 \mathrm{~kg} \mathrm{hl}^{-1}, \mathrm{n}=32\right)$ at the two higher fertilisation levels was observed $(p<0.01)$. In comparison to unfertilised control, PY3 and MBM significantly increased barley test 
Vol. 20(2011): 235-244.

Table 5. Average barley and oat 1000 grain weight (TGW, g), test weight $\left(\mathrm{kg} \mathrm{hl}^{-1}\right)$, protein content (\%), Protein yield (kg $\mathrm{ha}^{-1}$ ) and nitrogen use efficiency (NUE, \%) during two years.

\begin{tabular}{|c|c|c|c|c|c|c|c|c|c|c|c|}
\hline \multirow{2}{*}{$\begin{array}{l}\mathrm{N} \\
\left(\mathrm{kg} \mathrm{ha}^{-1}\right)\end{array}$} & \multirow{2}{*}{ Fertiliser } & \multicolumn{2}{|c|}{ TGW } & \multicolumn{2}{|c|}{ Test weight } & \multicolumn{2}{|c|}{ Protein content } & \multicolumn{2}{|c|}{ Protein yield } & \multicolumn{2}{|c|}{ NUE } \\
\hline & & Barley & Oat & Barley & Oat & Barley & Oat & Barley & Oat & Barley & Oat \\
\hline 0 & & 37.2 & 39.7 & 63.4 & 55.4 & 10.1 & 10.9 & 215.8 & 293.6 & & \\
\hline \multirow[t]{2}{*}{60} & PY3 & 39.0 & 40.2 & 64.6 & 56.5 & 10.2 & 11.6 & 306.0 & 456.5 & 24.2 & 43.5 \\
\hline & MBM & 38.4 & 40.3 & 64.3 & 55.7 & 10.6 & 11.0 & 328.5 & 414.2 & 30.2 & 31.0 \\
\hline \multirow[t]{2}{*}{90} & PY3 & 39.6 & 40.5 & 65.2 & 56.2 & 11.2 & 12.3 & 388.0 & 517.2 & 30.6 & 39.8 \\
\hline & MBM & 40.8 & 40.0 & 65.4 & 55.7 & 11.0 & 12.0 & 386.7 & 498.1 & 30.4 & 35.6 \\
\hline \multirow[t]{2}{*}{120} & PY3 & 41.4 & 40.6 & 65.9 & 54.9 & 12.0 & 13.0 & 452.6 & 592.7 & 31.5 & 39.9 \\
\hline & MBM & 42.0 & 40.0 & 65.6 & 55.0 & 11.8 & 13.1 & 459.4 & 594.9 & 32.6 & 40.7 \\
\hline
\end{tabular}

weight at the two highest fertilisation levels by $3.3 \%(p<0.05)$.

Oat test weight was on average $55.7 \mathrm{~kg} \mathrm{hl}^{-1}$ $\left(\mathrm{SD}=2.5 \mathrm{~kg} \mathrm{hl}^{-1}, \mathrm{n}=70\right)$. No consistent effect of either fertiliser types or levels on oat gain test weight were observed, over the three years (threeway interaction, $p<0.05$ ). In comparison to unfertilised control, neither fertilisers' effects were consistent during the three years. In the first two years, both fertilisers gave the same level oat test weight as the control. In the third year, PY3 at the highest fertilisation level decreased oat test weight by $4 \%(p<0.001)$ and MBM did not differ from the control at any of the three levels.

\section{Protein content}

Barley protein content (Table 5) did not differ between PY3 and MBM. At each step of increase in fertilisation rate, a significant increase in barley protein content was obtained from $10.5 \%$ (SD = $1.1 \%, \mathrm{n}=16)$ through $11.1 \%(\mathrm{SD}=1.1 \%, \mathrm{n}=16)$ to $11.9 \%(\mathrm{SD}=0.9 \%, \mathrm{n}=16)$ respectively $(p<$ $0.001)$. Compared to the control, with an average protein content of $10.1 \%(\mathrm{SD}=1.1 \%, \mathrm{n}=8), \mathrm{PY} 3$ at the two highest fertilisation levels and MBM at the highest fertilisation level significantly increased barley protein content by $15 \%$ and $18 \%$ respectively $(p<0.01)$.
Oat protein content did not differ between MBM and PY3. At each step of increase in fertilisation rate, a significant increase in oat protein content was obtained from $11.4 \%(\mathrm{SD}=1.3 \%$, $\mathrm{n}=23)$ through $12.2 \%(\mathrm{SD}=1.3 \%, \mathrm{n}=23)$ to $13.1 \%(\mathrm{SD}=1.1 \%, \mathrm{n}=23)$ respectively $(p<$ $0.01)$. Compared to unfertilised control, with an average protein content of $10.8 \%(\mathrm{SD}=1.0 \%, \mathrm{n}=$ 12), both fertilisers at the two highest fertilisation levels significantly increased oat protein content by $16 \%(p<0.01)$.

\section{Protein yield}

The protein yield of barley (Table 5) did not differ between MBM and PY3. At each step of increase in fertilisation rate, a significant $22 \%$ and $44 \%$ increase in barley protein yield was achieved ( $p$ $<0.01)$. Compared to the control, in which the average was $216 \mathrm{~kg} \mathrm{ha}^{-1}\left(\mathrm{SD}=79 \mathrm{~kg} \mathrm{ha}^{-1}, \mathrm{n}=8\right)$, irrespective of the type of fertiliser, fertilisation even at the lowest level significantly increased barley protein yield by 47\% ( $p<0.001)$.

As in the case of barley, oat protein yield did not differ between the two fertiliser types. At each step of increase in fertilisation rate, oat protein yield increased significantly by $16 \%$ and $36 \%$ from $435 \mathrm{~kg} \mathrm{ha}^{-1}\left(\mathrm{SD}=73 \mathrm{~kg} \mathrm{ha}^{-1}, \mathrm{n}=23\right)(p<$ $0.01)$. Compared to the control, in which the aver- 


\section{AGRICULTURAL AND FOOD SCIENCE}

Chen, L. et al. Meat bone meal as fertiliser for barley and oat

age was $294 \mathrm{~kg} \mathrm{ha}^{-1}\left(\mathrm{SD}=86 \mathrm{~kg} \mathrm{ha}^{-1}, \mathrm{n}=12\right), \mathrm{PY} 3$ even at the lowest level significantly increased oat protein yield by $56 \%(p<0.001)$. The fertilisation effect of MBM was not consistent during the three years $(p<0.05)$. In the first year, MBM significantly increased oat protein yield by $54 \%$ only at the two highest fertilisation rates $(p<0.001)$, while in the last two years, MBM increased oat protein yield by $61 \%$ even at the lowest fertilisation level $(p<0.001)$.

\section{Nitrogen use efficiency}

In the barley experiment NUE (Table 5) ranged from $9.2 \%$ to $40.2 \%$. No difference in NUE was observed between the two fertiliser types or fertilisation rates, but NUE in the second year (average $20.8 \%, \mathrm{SD}=9.1 \%, \mathrm{n}=24$ ) was significantly higher $(p<0.01)$ than in the first year (average 38.9\%, SD $=6.1 \%, \mathrm{n}=24)$.

In the oat experiment NUE ranged from $14.6 \%$ to $58.8 \%$. No significant difference appeared between the two fertilisers. NUE differed among the three fertilisation rates, but the difference was not consistent over the years (fertilisation rate $\times \mathrm{N}$ level, two way interaction, $p<0.05$ ).

\section{Discussion}

This study aimed at screening MBM as a fertiliser for spring cereals at variable application rates rather than testing any potential MBM-derived fertilisers of adjusted nutrient contents. Hence, the levels of all nutrients, not just $\mathrm{N}$, increased with increased application rates. A single nutrient's contribution to the results remained confounded with the N-level. The $\mathrm{N}$ rate itself was adjusted according to the total content, as plant availability and rate and seasonal pattern of release of $\mathrm{N}$ is not sufficiently known. We discuss the results with these reservations in mind.

In the present study, MBM was as effective as mineral fertiliser in increasing barley and oat grain yields, with equal nitrogen use efficiency. The result was consistent with those of experiments with winter and spring wheat in Sweden, which showed that MBM and urea produced equally good yield increases (Salomonsson et al. 1994, 1995). The doubling of the application rate from $857 \mathrm{~kg}$ to $1714 \mathrm{~kg} \mathrm{MBM} \mathrm{ha}^{-1}$ did not significantly increase barley and oat grain yield in the first year; it did, however, in the second year. A possible explanation could be better initial nutrient status in the soil in the first year than in the second year. Lundström and Lindén (2001) found that in soils with high plant-available $\mathrm{N}$ that was partly released in spring and partly released by mineralisation during the growing season, an $\mathrm{N}$ application of as little as $40 \mathrm{~kg} \mathrm{~N} \mathrm{ha}^{-1}$ in MBM was sufficient. Jeng et al. (2006), experimenting with spring barley, obtained a yield increase with $500 \mathrm{~kg} \mathrm{MBM} \mathrm{ha-1}$, but no further yield increase with increased application rates. Obviously, the fertilisation effect of MBM is determined by soil nutrient status.

The average $\mathrm{C} / \mathrm{N}$ ratio in $\mathrm{MBM}$ is around 3-4 (Jeng et al. 2004), favourable to microbial mineralisation. Rapid mineralisation of $\mathrm{N}$ from MBM in soil was found by Chaves et al. (2005) and by Mondini et al. (2008). Jeng et al. (2004), experimenting with spring cereals, however, found that the application of small amounts of MBM $(60 \mathrm{~kg}$ $\mathrm{N} \mathrm{ha}^{-1}$ ) resulted in a high proportion of immobilisation shortly after the seedling stage. When the application rate was higher, the immobilisation had a lesser effect on $\mathrm{N}$ uptake. The MBM they used contained $7 \% \mathrm{~N}$, of which $2.5 \%$ was soluble ammonium- $\mathrm{N}$ and the remaining $4.5 \%$ organic substances.

In addition to $\mathrm{N}$, the $\mathrm{P}$ effect of MBM is also considerable. Ylivainio et al. (2007) found that although $\mathrm{P}$ in MBM was mainly acid soluble early on, it was eventually converted to a plant-available form. In the first year, only $19 \%$ of the P became available to the plants, but in the third year of the experiment, MBM was equal to dairy manure and super phosphate in producing ryegrass yield (Ylivainio et al. 2007). Moreover, MBM serves not only as a fertiliser, but by increasing activity of microorganisms, it serves as soil conditioner (Mondini et al. 2008). Kahiluoto and Vestberg (1998) reported 
Vol. 20(2011): 235-244.

that MBM as well as manure enhanced arbuscular mycorrhiza, while mineral fertiliser suppressed it.

In our experiment, the residual effect on oat grain yield of MBM was better than the effect of the mineral fertiliser. With both, the residual yield increase was significant only at the highest rates of application over the previous three years. The slow release of $\mathrm{P}$, and even some residual effect from the mineralisation of organic $\mathrm{N}$ in the years that followed, may explain the advantage of MBM over mineral fertiliser. Further process-oriented studies covering more than one season's residual effect are needed to understand the long-term effects of MBM application.

The market value of a grain crop is largely determined by its test weight and TGW. Like the mineral fertiliser, MBM performed well in building up barley and oat grain TGW and test weight. Protein content is an important factor of grain quality, and also contributes to the market price. Protein content is often restricted by N supply. MBM showed a similar good effect on barley and oat, which was in line with results from spring and winter wheat published by Salomonsson et al. $(1994,1995)$ and by Fredriksson et al. (1997, 1998). Protein yield is determined by grain yield and protein content. As the $\mathrm{N}$ level increased, both the grain yield and protein content increased, leading to an increase in protein yield. As with the mineral fertiliser, MBM showed the same effect in increasing grain protein yield.

Raising $\mathrm{N}$ results in taller plants and may lead to lodging, which increases the risk of quality loss. Optimal $\mathrm{N}$ management must balance yield improvement against reductions in grain quality. In the present study, lodging was negligible in all treatments, and did not contribute to the results. Mineral fertilisation and MBM produced equally good quality at all $\mathrm{N}$ application levels.

The nutrient content of MBM (7-5-1) differs from crop requirements. The N/P uptake ratios for most crops range from 4.5 to 9, so applying MBM according to $\mathrm{N}$ needs would lead to a surplus of $\mathrm{P}$. According to Ylivainio et al. (2007), only about $20 \%$ of the P in MBM is immediately available to plants. Thus, the immediately plant-available N/P ratio would be about eight, which is close to crops' needs. Therefore MBM can be a source of $\mathrm{P}$ for organic farming and especially for perennial plants and pastures, which can absorb large quantities of P. In this way, the runoff of $\mathrm{P}$ can be reduced.

Another essential macronutrient for crops (is potassium. To balance the nutrient contents in $\mathrm{MBM}, \mathrm{K}$ from different by-products, such as vinasse from the sugar beet industry, could be added to MBM to achieve NPK contents more optimal for crops. Formulation, such as granulation or slurring, could be developed. Such development and testing would be needed for both agricultural and horticultural crops.

Jeng and Vagstad (2009) found that autumn and early spring MBM application may cause nutrient loss in the environment, especially leaching or run off of $\mathrm{N}$ and P. Thus, the timing of MBM application should be close to sowing or planting, or MBM could be applied to an established crop. In Finnish conditions, granulated fertiliser for arable crops is usually applied simultaneously with the seed by a combined application machine. This is an additional argument in support of granulated MBM products. The study did not assess environmental risks or benefits. The further development of MBM fertilisation should include environmental impact assessment.

Considering the high $\mathrm{N}$ and $\mathrm{P}$ content of MBM, disposal in landfills or incineration in specific facilities for garbage incineration, power stations and the cement industry seems wasteful. Because $70 \%$ of the MBM produced originates from "no risk" or "low risk" material, meals of animal origin should be recycled within the agrifood system.

We conclude that MBM is an efficient fertiliser for cereals. We recommend product development for improved nutrient ratios by mixing MBM with other suitable by-products of the food industry, and formulation into granulated products. More research in P dynamics in MBM in soil is needed, both for crop management and for evaluating environmental risks. Recycling nutrients within the agrifood system is an important path towards industrial ecologisation within the food sector. 


\section{AGRICULTURAL AND FOOD SCIENCE}

Chen, L. et al. Meat bone meal as fertiliser for barley and oat

\section{References}

Bekele, T. \& Höfner, W. 1993. Effects of different phosphate fertilisers on yield of barley and rape seed on reddish brown soils of the Ethiopian highlands. Nutrient Cycling in Agroecosystems 34: 243-250.

Brewer, M.S. 1999. Current status of bovine spongiform encephalopathy - A review. Journal of Muscle Food 10: 97-117.

Chaves, C., Canet, R., Albiach, R., Marin, J., \& Pomares, F., 2005. Meat and bone meal: fertilizing values and rates of nitrogen mineralization. In: Bernal, M.P., Moral, R., Clemente, R., Paredes, C. (Eds.). Proceedings of the 11th International Conference RAMIRAN, Murcia, Spain, vol. 1, 6-9 October 2004, p. 177-180.

FAO 2006. World reference base for soil resources 2006. A framework for international classification, correlation and communication. Food and Agriculture Organization of the United Nations, Rome. 103 p.

Fredriksson, H., Salomonsson, L. \& Salomonsson, A. 1997. Wheat cultivated with organic fertilisers and urea: baking performance and dough properties. Acta Agriculturae Scandinavica, Section B - Soil \& Plant Science 47: $35-42$.

Fredriksson, H., Salomonsson, L., Andersson, R., Salomonsson, A.-C. 1998. Effects of Protein and Starch Characteristics on the Baking Properties of Wheat Cultivated by Different Strategies with Organic Fertilisers and Urea. Acta agriculturæ Scandinavica. Section B Soil \& Plant Science 48: 49.

Frosch, R.A. \& Gallopoulos, N.E. 1989. Strategies for manufacturing. Scientific American 261: 144-152.

Gomez, K. A. \& Gomez, A. A. 1984. Statistical Procedures in Agricultural Research, 2nd edition. 680 p. New York, Wiley

Graedel, T.E. 1996. On the concept of industrial ecology. Annual Review of Energy and Environment 21: 69-98.

Jeng, A., Haraldsen, T.K., Vagstad, N., Grønlund, A \& Tveitnes, S. 2004. Meat and bone meal as nitrogen fertiliser to cereals in Norway. Agricultural and Food Science 13: 268-275.

Jeng, A.S., Haraldsen, T.K., Grønlund, A. \& Pedersen, P.A. 2006. Meat and bone meal as nitrogen and phosphorus fertiliser to cereals and rye grass. Nutrient Cycling in Agroecosystems 76: 183-191.

Jeng, A.S. \& Vagstad, N. 2008. Potential nitrogen and phosphorus leaching from soils fertilized with meat and bone meal. Acta Agriculturae Scandinavica, Section B - Plant \& Soil Science 59: 1-8.
Kahiluoto, H. \& Vestberg, M. 1998. The effect of arbuscular mycorrhiza on biomass production and phosphorus uptake from sparingly soluble sources by leek (Allium porrum L.) In Finnish field soils. Biological Agriculture and Horticulture 16: 65-85.

Lazarovits, G., Conn, K. \& Potter, J. 1999. Reduction of potato scab, Verticillium wilt, and nematodes by soymeal and meat and bone meal in two Ontario potato fields. Canadian Journal of Plant Pathology 21: 345-353

Lundström, C. \& Lindén, B. 2001. Nitrogen effects of human urine, meat bone meal (Biofer) and chicken manure (Binadan) as fertilisers applied to winter wheat, spring wheat, and spring barley in organic farming. Swedish University of Agricultural Sciences, Department of Agricultural, Skara, Series B crops and soils, report 8:51.

Mondini, C., Cayuela, M.L., Sinicco, T., Sanchez-Monedero, M., Bertolone, E. \& Bardi, L. 2008. Soil application of meat and bone meal. Short-term effects on mineralization dynamics and soil biochemical and microbiological properties. Soil Biology \& Biochemistry 40: 462-474.

Peltovuori, T. 1999. Precision of commercial soil testing practice for phosphorus fertilizer recommendations in Finland. Agricultural and Food Science in Finland 8: 299-308.

Salomonsson, L., Jonsson, A., Salomonsson, A. \& Nilsson, G. 1994. Effects of organic fertilisers and urea when applied to spring wheat. Acta agriculturæ Scandinavica. Section B, Soil and Plant Science 44: 170.

Salomonsson, L., Salomonsson, A., Olofsson, S. \& Jonsson, A. 1995. Effects of organic fertilisers and urea when applied to winter wheat. Acta agriculturæ Scandinavica. Section B, Soil and Plant Science 45: 171.

Salminen, E. 2002. Finnish expert report on best available techniques in slaughterhouses and installations for the disposal or recycling of animal carcasses and animal waste. The Finnish Environment 539: 42.

Vuorinen, J. \& Mäkitie, O. 1955. The method of soil testing used in Finland. Agroecological publications 63:1-14.

Werner, W. 2003. Complementary nutrient sources. In: IFA-FAO Agriculture Conference Global Food Security and the Role of Sustainable Fertilisation, Rome, 2628 March 2003.

Yli-Halla, M., Mokma, D., Peltovuori, T. \& Sippola, J. 2000. Suomalaisia maaprofiileja (Abstract: Agricultural soil profiles in Finland and their classification). Maatalouden Tutkimuskeskuksen Julkaisuja, Sarja A 78. 104 p. (In Finnish).

Ylivainio, K., Uusitalo, R. \& Turtola, E. 2007. Meat bone meal and fox manure as $\mathrm{P}$ sources for ryegrass (Lolium multiflorum) grown on a limed soil. Nutrient Cycling in Agroecosystems, 81:267-278. 